University News: Bradford Institute of Technology

Dr. D. W. Mathieson, reader in pharmaceutical chemistry in the University of London, has been appointed professor of pharmaceutical chemistry.

Strathclyde

Dr. W. C. Bowman, reader in pharmacology in the School of Pharmacy, University of London, has been appointed professor of experimental pharmacology in the University of Strathclyde. Dr. Bowman's major research interest is in the mechanism of action of drugs which interfere with synaptic and neuro-effector transmission.

Sheffield

Prof. G. J. HorJTink, professor of chemistry in the University of Amsterdam, has been appointed to the chair of physical chemistry. Prof. R. McWeeny, professor of theoretical chemistry in the University of Keele, has been appointed to the chair of theoretical chomistry.

Swansea

Mr. J. Otiver, senior lecturer in the Department of Geography, has been appointed to the newly established second chair of geography in the University College of Swansea.

\section{Awards and Appointments}

Dr. Peyton Rous has received the Paul Ehrlich and Ludwig Darmstaedter Prize, which is the highest medical award of West Germany.

Prof. G. Puppi has been elected chairman of the CERN Scientific Policy Committee, in succession to Prof. L. Leprince-Ringuet.

DR. D. H. WHIFFEN was appointed superintendent of the Division of Molecular Science at the National Physical Laboratory, Teddington, Middlesex, as from April 1.

H. B. STEWART, JUN., formerly chief oceanographer of the Coast and Geodetic Survey, has been appointed head of the New Institute for Oceanography of the U.S. Environmental Science Services Administration

\section{Announcements}

THE U.S. National Academy of Sciences and the Academy of the Socialist Republic of Romania have announced a three-year exchange programme, providing for visits of up to one year by individual scientists of the two countries to lecture and to conduct research. The new programme is the third to go into effect this year between the U.S. Academy and one of its sister institutions in Eastern Europe.

A symposium on "Terpenoids in Plants", organized by the Phytochemical Group, will be held in the University College of Wales, Aberystwyth, during April 12-14. Further information can be obtained from Mr. A. H. Williams, Research Station, Long Ashton, Bristol.

A ONE-DAY symposium on "The Environmental Stability of Low-voltage Contacts" will be held at the Luton College of Technology on April 13. Further information can be obtained from Dr. M. G. Parker, Luton College of Technology, Park Square, Luton, Bedfordshire.

THE second international conference on "Electron and Ion Beams" will be held in New York during April 17-20. Further information can be obtained from the Secretary, Institute of Metals Division, Metallurgical Society of A.I.M.E., 345 East 47 th Street, New York.

A JoInt meeting of the Microchemical Methods Group and the Scottish Section of the Society for Analytical Chemistry will be held in the University of Edinburgh during April 15-17. Further information can be obtained from the Society for Analytical Chemistry, 14 Belgrave Square, London, S.W.1.

A ONE-DAY colloquium on "Winning of Chemicals from Flames" will bo held by the British Section of the Combustion Institute in the University of Sheffield on April 15. Further information can be obtained from Prof. W. G. Parker, Department of Chemistry, College of Advanced Technology, Birmingham 4.

A seminar on "The Dynamic Rolo of Molecular Constituents in Plant-Parasite Interaction", sponsored joint]y under the United States-Japan Co-operative Science Program by the National Science Foundation and the Japanese Society for Promotion of Science, will be held in Gamagori during May 15-21. Further information can be obtained from Dr. C. J. Mirocha, Department of Plant Pathology and Physiology, University of Minnesota, St. Paul.

\title{
THE NIGHT SKY IN MAY
}

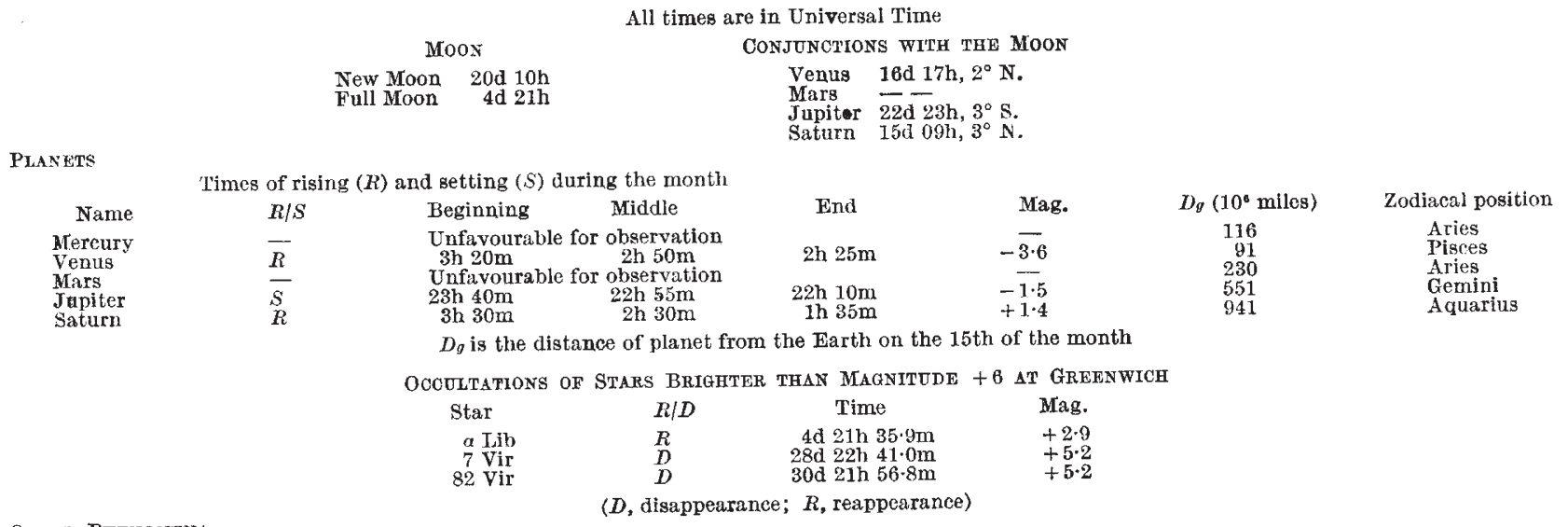

Other Phenomena

1d $18 \mathrm{~h}$, Venus $1^{\circ} \mathrm{N}$ of Saturn.
$4 \mathrm{~d}$, Penumbral eclipse of Moon:

20d, Annular eclipse of Sun:
Moon enters Penumbra Mid eclipse Moon leaves Penumbra
Eclipse begins Central eclipse begins Central cclipse at local apparent noon Central eclipse ends Eelipse ends
$19 \mathrm{~h} 07 \mathrm{~m}$ $21 \mathrm{~h} 12 \mathrm{~m}$ $23 \mathrm{~h} 17 \mathrm{~m}$ 7h $54 \mathrm{~m}$

$9 \mathrm{~h} 51 \mathrm{~m}$ $11 \mathrm{~h} 23 \mathrm{~m}$
Beginning of eclipse visible in Eastern Gurope, Africa, Asia, Australia, end of eclipse visible Western Europe, Africa and South America.

Visible Brazil, Atlantic, North and Central Africa, Europe, Asia. 